\title{
Kinetics of alkaline phosphatase activity, and effect of phosphate enrichment: a case study in the NW African upwelling region
}

\author{
Marta Sebastián ${ }^{1, *}$, Javier Arístegui², María F. Montero², F. Xavier Niell ${ }^{3}$ \\ ${ }^{1}$ Centro Oceanográfico de Málaga, Instituto Español de Oceanografía, PO Box 285, Fuengirola, 29640 Málaga, Spain \\ ${ }^{2}$ Facultad de Ciencias del Mar, Universidad de Las Palmas de Gran Canaria, 35017 Las Palmas, Spain \\ ${ }^{3}$ Departamento de Ecologia, Facultad de Ciencias, Universidad de Málaga, 29071 Málaga, Spain
}

\begin{abstract}
Alkaline phosphatase (AP) kinetic experiments were performed in a broad range of trophic conditions in the transition zone between the North African upwelling and the open ocean, in order to investigate the effect of nutrient richness on kinetic parameters. Turnover times decreased from $224 \mathrm{~h}$ in the open ocean to $13 \mathrm{~h}$ in the upwelling region. $K+S_{\mathrm{n}}$ showed the lowest values at the most eutrophic station $(27 \mathrm{nM})$, while at this station $V_{\mathrm{m}}$ reached its maximum value of $2.1 \mathrm{nM} \mathrm{h}^{-1}$. Nevertheless, as multiphasic kinetics occurred, kinetic parameter values depended largely on the fitting technique used. Response of AP activity (APA) to phosphate enrichment was also studied along a trophic gradient at the surface and the chlorophyll maximum level. Inhibition of APA reached $50 \%$ with only $0.1 \mu \mathrm{M}$ of phosphate added, and rose to 80 to $96 \%$ inhibition by additions of $1 \mu \mathrm{M}$ at the oligotrophic stations, whereas in the most eutrophic station, phosphate amendments had no effect. Inhibition was higher at the surface and towards oligotrophy. The lack of inhibition in the upwelling station and the low $K+S_{\mathrm{n}}$ encountered suggest that the APA of eutrophic waters was mainly from bacterial origin. This supports the hypothesis of APA being mainly involved in supplying easily assimilable organic carbon to bacteria in eutrophic waters.
\end{abstract}

KEY WORDS: Alkaline phosphatase $\cdot$ Kinetic parameters $\cdot$ Phosphorus $\cdot$ Trophic gradient $\cdot$ Turnover Resale or republication not permitted without written consent of the publisher

\section{INTRODUCTION}

Phosphorus in marine systems has received limited attention, since growth and production of planktonic organisms in the ocean have traditionally been considered as limited by the availability of nitrogen. Growing evidence that $\mathrm{P}$ is the limiting nutrient in some coastal systems (Thingstad et al. 1993) and oligotrophic oceans (Cotner et al. 1997, Karl \& Yanagi 1997) have resulted in several recent studies being conducted (Rivkin \& Anderson 1997, Thingstad et al. 1998, Zohary et al. 1998, Cañellas et al. 2000, Van Wambeke et al. 2002).

Phosphate is frequently exhausted in the euphotic zone of the oceans. It often represents less than $25 \%$ of the total dissolved phosphorus pool in these systems, and the remaining $75 \%$ occurs in the form of dissolved organic phosphorus and inorganic polyphosphate compounds (Karl \& Yanagi 1997). Consequently, the cycling of TDP could potentially control P availability and affect biomass and production of the phytoplankton and bacterial communities.

The importance of microbial enzymatic activities to the mobilisation, transformation and turnover of organic and inorganic compounds in aquatic environments has been proved during the last 2 decades (e.g. Hoppe 1983, Chrôst 1990, Cotner \& Wetzel 1991). The use of combined $P$ compounds requires the action of specific hydrolytic enzymes such as phosphatases (Perry 1972) and nucleotidases (Ammerman \& Azam 1985). Alkaline phosphatase (AP) is the most characterised enzyme in studies of degradation of organic phosphorus compounds (e.g. Kobori \& Taga 1979, Hino 1988, Ammerman \& Azam 1991, Hantke et al. 1996). 
Most of the studies dealing with AP have been conducted in freshwater systems (e.g. Chrôst \& Overbeck 1987, Pick et al. 1987, Boavida \& Heath 1988, Hernández et al. 1996) and in coastal or freshwater-influenced marine systems (Taft et al. 1977, Hoppe 1983, Thingstad et al. 1993, Nausch 1998, Cotner et al. 2000). However, data in marine oligotrophic environments are scarce (e.g. Perry 1972, Cotner et al. 1997, Thingstad et al. 1998, Cañellas et al. 2000, Van Wambeke et al. 2002). Studies carried out in several coastal marine habitats concluded that AP hydrolyses 10 to $50 \%$ of the total soluble non-reactive phosphorus pool (Strickland \& Solorzano 1966, Taft et al. 1977, Kobori \& Taga 1979). Originally, AP was thought to be mainly synthesised by phytoplankton (Perry 1972, Chrôst \& Overbeck 1987), but it is widespread in bacteria (Kobori \& Taga 1979, Martinez et al. 1996) and is also produced by zooplankton (Boavida \& Heath 1984, Jansson 1988). The phosphatase group of enzymes has broad substrate specificity and hydrolyses ester bonds between phosphates and dissolved organic molecules, making phosphate available for cellular assimilation. As they may be regulated (induced or repressed) by the occurring ambient inorganic phosphate concentration or by intracellular P concentrations (Chrôst \& Overbeck 1987), alkaline phosphatase activity (APA) has been widely used as an index of P-status of phytoplankton cells. On the other hand, the mechanism of regulation of bacterial phosphatases seems to be linked to the $\mathrm{C}$ cycle, as bacteria can produce APA to supply their metabolism with the organic $\mathrm{C}$ substrates which are also final products of phosphoester hydrolysis (Chrôst 1990, Siuda \& Güde 1994). Thus, APA seems to have a multiple function in aquatic environments by supplying the pools of phosphorus and available organic carbon simultaneously.

In order to provide more information about APA characteristics in the marine system, we studied this activity in different trophic scenarios. The Canary Islands region is characterised by an intricate hydrological pattern of mesoscale structures, which leads to the occurrence of a broad range of trophic conditions in short spatial scales, and thus provides an appropriate study area for testing APA behaviour in marine systems.

Here, we carried out kinetics experiments at stations of different eutrophic level, ranging from the oligotrophic open ocean to the upwelling area. We also examined the effects of phosphate amendments on hydrolysis rates to see the regulation of APA by phosphate along a trophic gradient.

\section{MATERIALS AND METHODS}

Field data were obtained on board BIO 'Hespérides', on cruise FAX-9908, from 5 to 27 August 1999. The cruise was carried out within the CANIGO EU project framework.

Hydrological data. At each station, a General Oceanics Mk III CTD was used to obtain vertical profiles of temperature, salinity, density and fluorescence. Water samples for nutrient and biological determinations were collected at discrete depths (from 0 to $500 \mathrm{~m}$ ) with $24 \times 121$ Niskin bottles from a rosette sampler attached to the CTD. Inorganic nutrients were measured colorimetrically by continuous flow analysis, using a Technicon-Bran Luebbe AA II AutoAnalyzer.

Chl a. Chl a (hereafter referred to as chl) was estimated fluorometrically by means of a Turner Designs bench fluorometer, previously calibrated with pure chl (Sigma), following the recommendations of HolmHansen et al. (1965). Seawater samples (500 ml) were filtered through Whatman GF/F fibre filters. Pigments were extracted on-board in cold acetone (90\% v/v) for $24 \mathrm{~h}$. Extracted chl samples were used to calibrate the voltage readings of the submersible fluorometer (SeaTech 57S) linked to the CTD unit. Water-column integration of chl concentration was performed with the Kaleida Graph Software.

Dissolved inorganic phosphorus (Pi), total phosphorus (TP) and particulate phosphorus (PP). For Pi and TP determination, water samples were immediately frozen at $-20^{\circ} \mathrm{C}$ and preserved frozen until their analysis. Dissolved inorganic phosphorus was estimated as soluble reactive phosphorus by the malachite green method (Fernández et al. 1985). For PP determinations 21 samples of water were filtered through Whatman GF/F fibre filters and then preserved frozen $\left(-60^{\circ} \mathrm{C}\right)$ until their analysis. TP (water samples) and PP (filters) were digested by means of the perchloric-nitric acid procedure (Sommers \& Nelson 1972) and afterwards estimated as soluble reactive phosphorus by the malachite green method (Fernández et al. 1985).

Diffusive Pi fluxes across the nutricline. Diffusive fluxes were estimated assuming that the only properties controlling the diffusion coefficient, $\mathrm{Kz}$, are the dissipation rate of kinetic energy $(\varepsilon)$ and the buoyancy frequency $\left(\mathrm{N}^{2}\right)$, thus:

$$
\mathrm{Kz}=\mathrm{A} \varepsilon \mathrm{N}^{-2} \quad\left(\mathrm{~m}^{2} \mathrm{~s}^{-1}\right)
$$

where A is a empirical constant close to 0.25 (Linden 1971, Oakey 1982). $\varepsilon$, under pure wind-stress forcing, should follow:

$$
\varepsilon(z)=u^{* 3} / \mathrm{k} z \quad\left(\mathrm{~m}^{2} \mathrm{~s}^{-3}\right)
$$

where $\mathrm{k} \sim 0.4$ is von Karman's constant, $z$ is the vertical coordinate and $u^{*}$ is the friction velocity, expressed as:

$$
u^{*}=f_{\mathrm{C}} U_{10} \quad\left(\mathrm{~m} \mathrm{~s}^{-1}\right)
$$

where $f \mathrm{c}$ is an empirical coefficient $(0.00123$, Oakey \& Elliott 1982) and $U_{10}$ is the mean wind speed $10 \mathrm{~m}$ 
above the sea surface $\left(U_{10} \sim 10 \mathrm{~m} \mathrm{~s}^{-1}\right.$ for the cruise period).

$\mathrm{N}^{2}$ can be derived directly from the CTD profiles according to the equation:

$$
\mathrm{N}^{2}=\left(g / \rho_{\mathrm{w}}\right)(\partial \rho / \partial \mathrm{z}) \quad\left(\mathrm{s}^{-1}\right)
$$

where $g$ is the acceleration due to gravity $\left(9.8 \mathrm{~ms}^{-2}\right), \rho_{\mathrm{w}}$ is seawater density $\left(1027 \mathrm{~kg} \mathrm{~m}^{-3}\right)$ and $\partial \rho / \partial \mathrm{z}$ is the vertical density gradient.

Vertical phosphate fluxes across the nutricline were calculated from the product of the gradient of phosphate concentration across the nutricline, determined by linear regression analysis, and the estimated mean diffusion coefficient for the nutricline layer.

Proteins. Proteins were determined according to the Peterson's (1977) modification of the Lowry et al. (1951) method, using a protein assay kit provided by Sigma. Water samples (5 l) were concentrated on GF/F filters. Proteins were extracted by grinding the filters with Lowry reagent directly and diluting with water afterwards. Sodium dodecylsulfate included in the Lowry reagent facilitated the dissolution of relatively insoluble lipoproteins. Replicate assays were run for each sample. BSA standards with protein concentrations between 4 and $400 \mathrm{\mu g} \mathrm{l}^{-1}$ were run at the same time to obtain a calibration curve.

Bacterial abundance. Heterotrophic bacteria (HB) were counted by flow cytometry, using a FACScalibur (Becton \& Dickinson). Samples $(4 \mathrm{ml})$ were fixed with $2 \%$ final concentration of formaldehyde, incubated for 15 to $30 \mathrm{~min}$ at $4{ }^{\circ} \mathrm{C}$, and then stored frozen in liquid nitrogen until analysed. To count HB, $200 \mu \mathrm{l}$ of sample was stained with a DMS-diluted SYTO-13 (Molecular Probes) stock (10:1) at $2.5 \mu \mathrm{M}$ final concentration. Bacteria were identified by their signatures in a plot of side scatter (SSC) versus green fluorescence (FL1). Samples were run at low speed until 10000 events were acquired. A solution of yellow-green $1 \mu \mathrm{m}$ latex beads $\left(\sim 10^{6}\right.$ beads $\left.\mathrm{m} \mathrm{l}^{-1}\right)$ was added as an internal standard (Polysciences). Cell abundances were calculated from bead concentrations. The bead solution was checked daily through epifluorescence microscopy counting. The conversion factor for calculation of bacterial biomass was $20 \mathrm{fg} \mathrm{C} \mathrm{cell}^{-1}$ (Lee \& Fuhrman 1987).

Alkaline phosphatase activity (APA). APA was measured using the fluorogenic substrate methyl-umbelliferyl phosphate (MUF-P; Sigma). MUF-P was dissolved in cold sterile artificial seawater and then diluted to obtain the working solutions that were frozen until use on board. The methyllumbelliferon (MUF) produced after the assay was detected as increase in fluorescence by using a Shimadzu RF-3501 PC spectro- fluorometer. A standard curve with MUF (Sigma) was used to quantify the amount of MUF produced from APA.

Kinetic approach: Kinetic measurements were performed at the chl maximum level at 3 stations of different hydrographical characteristics to study regional variation: 1 open ocean station (Stn 2) located upstream of the islands near La Palma, one downstream Fuerteventura (Stn 102) and one to the south affected by the presence of a cyclonic eddy (Stn 45) (Fig. 1).

Assays were run in duplicate. Varying amounts of MUF-P were added to samples to obtain concentrations from 0 to $25 \mu \mathrm{M}$. Autoclaved or zero-time samples were used as blanks. Spontaneous breakdown of the MUF-substrate when added to the samples was observed; since this breakdown was observed to be proportional to its concentration, we did separate duplicate blanks for each amount of MUF-substrate added. Incubations lasted for 2 to $3 \mathrm{~h}$.

Estimation of kinetic parameters, $V_{\mathrm{m}}$ and $K+S_{\mathrm{n}}$ : The relationship of enzymatic activity to substrate concentration can be generally described by the Michaelis-Menten equation:

$$
V=\frac{V_{\mathrm{m}} \times S}{K+S}
$$

where $V$ is the rate of uptake or metabolism $\left(\mu \mathrm{M} \mathrm{h}^{-1}\right)$ of a substance present at a concentration of $S(\mu \mathrm{M}), V_{\mathrm{m}}$ is the asymptote towards which $V$ tends (maximum velocity), and $K$ is the value of $S$ for which $V$ is half of $V_{\mathrm{m}}$ (half saturation constant).

Kinetic studies are performed by adding different substrate to concentrations. In many cases, the ambi-

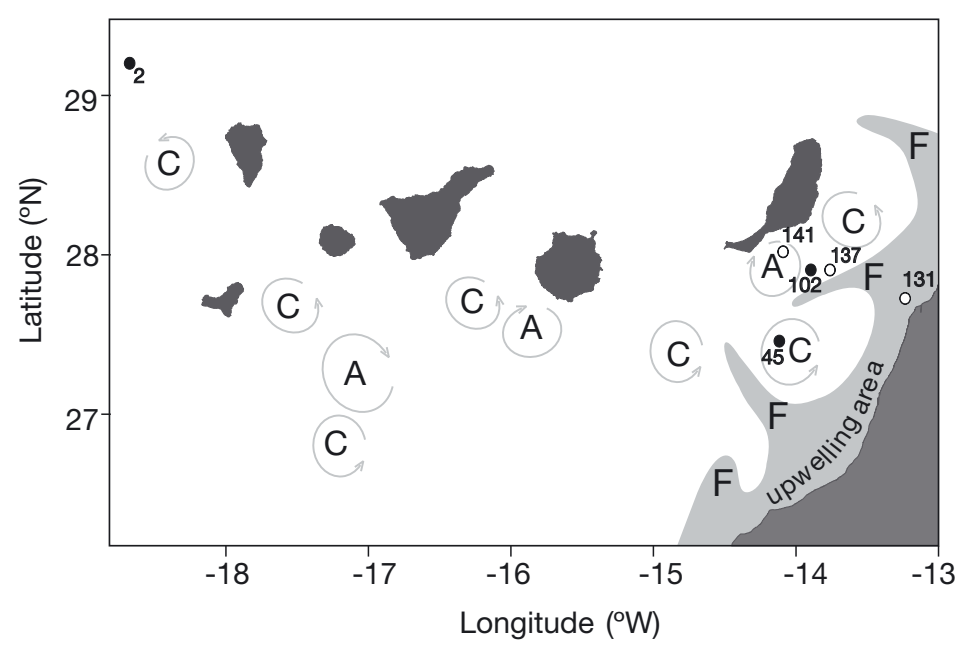

Fig. 1. Diagram of mesoscale structures (A: anticyclone, C: cyclone, F: upwelling filament) in the Canary Current upwelling system. Black dots: stations of kinetic experiments. White dots: stations of dissolved inorganic phosphorus (Pi) addition experiments 
ent concentration of the substrate $\left(S_{\mathrm{n}}\right)$ is unknown. Thus, the effective concentration $S$ is the sum of $S_{\mathrm{n}}$ and the added substrate concentration $\left(S_{\mathrm{a}}\right)$ and Eq. (1) becomes:

$$
V=\frac{V_{\mathrm{m}} \times\left(S_{\mathrm{n}}+S_{\mathrm{a}}\right)}{K+\left(S_{\mathrm{n}}+S_{\mathrm{a}}\right)}
$$

Following the procedure developed by Li (1983), this equation can be transformed to:

$$
r=\frac{V_{\mathrm{m}}}{K^{\prime}+S_{\mathrm{a}}}
$$

(hereafter referred to as the $\mathrm{Li}$ parameterisation or $\mathrm{Li}$ model) where $r$ is turnover rate, and $K^{\prime}=K+S_{\mathrm{n}}$. According to standard practice, Eq. (2) can also be transformed to:

$$
T=\frac{K^{\prime}}{V_{\mathrm{m}}}+\frac{S_{\mathrm{a}}}{V_{\mathrm{m}}}
$$

known as the Wright-Hobbie linearization (Wright \& Hobbie 1966), where $T$ is the turnover time.

However, Li (1983) compared the goodness-of-fits and precision of parameter estimates of both equations, and concluded that estimating parameters from a linear regression of unweighted $T$ on $S_{\mathrm{a}}$ (Eq. 4 ) is statistically less satisfactory than from a direct nonlinear fit of $r$ to $S_{\mathrm{a}}$ (Eq. 3). Therefore we chose the Li model to estimate kinetic parameters.

The turnover rate in unamended water samples $\left(r_{\mathrm{n}}\right)$ would be estimated as $V_{\mathrm{m}} /\left(K+S_{\mathrm{n}}\right)$, thus substituting $S_{\mathrm{a}}=0$ in the Li equation. The natural turnover time $(T)$ is estimated as $1 / r_{\mathrm{n}}$.

The Li-model was fitted using S-plus software.

Effect of phosphate in APA. To test the effect of the addition of phosphate on APA, experiments were done at 3 selected stations along a transect extending from upwelled waters to warmer nutrient-poor stratified waters near the Fuerteventura Island. One station was

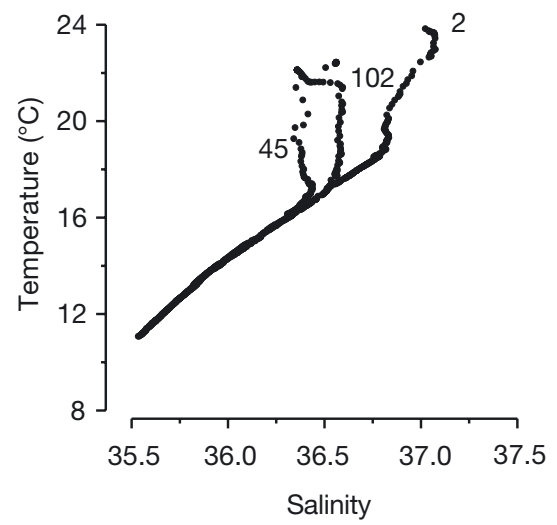

Fig. 2. Temperature-salinity plots of stations where kinetic experiments were done located in the upwelling area (Stn 131), one in the channel between the African Coast and the island (Stn 137), and one near Fuerteventura (Stn 141) (Fig. 1). Samples were taken from surface and chl maximum (CM). As in the upwelled areas, the level of CM reached the surface, for those areas we obtained one sample from the surface and another from subsurface waters.

For APA determination, a working solution of MUF$\mathrm{P}$ was added to water samples to give $100 \mathrm{nM}$ final concentration. We decided to do near-tracer assays in order to estimate actual in situ substrate turnover times, and also because non-saturating substrate additions allow greater sensitivity than higher substrate additions (which have high background fluorescence).

In each experiment, APA assays were carried out in triplicate at in situ temperatures in the absence and presence of increasing $\mathrm{Pi}$ concentrations (i.e. 0.1, 0.25, 0.5 , and $1 \mu \mathrm{M} \mathrm{K}_{2} \mathrm{HPO}_{4}$ ). Incubations lasted $4.25 \mathrm{~h}$. The time course of MUF production (i.e. phosphate release) was observed to be linear for at least $9 \mathrm{~h}$ (Sebastian et al. unpubl.).

\section{RESULTS}

The upwelling/open ocean transition in the Canary Islands region is subjected to great mesoscale variability, as can be observed in Fig. 1. Upwelling filaments in the time of the study extended far offshore from the shelf, and a series of cyclonic and anticyclonic eddies appeared downstream of the islands of the Canary archipelago. The lateral entrainment of non-local nearsurface waters by upwelling filaments, and the secondary vertical circulation produced by eddy mean flow interactions provide likely mechanisms of enrichment of offshore nutrient-depleted waters (Barton et al. unpubl., Sebastián et al. unpubl.).

As a result, high variability in biological variables in the area was also observed. Despite the fact that generally low mean values of chl were obtained $(\sim 0.6 \mu \mathrm{g}$ chl $\mathrm{l}^{-1}$ in the $\left.\mathrm{CM}\right)$, the occurrence of upwelling filaments and cyclonic eddies promoted the uplifting of the nutricline and the CM, and chl at this level increased (>1.2 $\mathrm{gg} \mathrm{chl}^{-1}$ in the CM).

\section{Alkaline phosphatase kinetics}

Temperature-salinity (T-S) diagrams of the stations sampled for kinetic experiments (Stns 2, 102 and 45, Fig. 1) are shown in Fig. 2. The 3 stations were located along a coastal/open ocean gradient, and showed very different T-S properties. Stn 2, the offshore station, showed higher salinity and temperature values than 
Stn 102, which also showed higher values of salinity at surface than $\operatorname{Stn} 45$. As a result, the 3 stations exhibited different trophic states, as reflected by the uplifting of the nutricline and the $\mathrm{CM}$ and the increase in water-column-integrated chl towards Stn 45 (Table 1). Stn 45 presented a clear eutrophic character compared to the other 2 stations, with the nutricline occurring more than $70 \mathrm{~m}$ shallower and with a much higher phosphate concentration at the CM level. Although Stn 45 is located slightly further offshore than Stn 102, its eutrophic character is due to the occurrence of a cyclonic eddy (Barton et al. unpubl.).

Kinetic analyses demonstrated varying results at the different stations tested. Results showed that APA followed a Michaelis-Menten (M-M) kinetic trend in all cases (Fig. 3a-c). Nevertheless, results from the eutrophic station (Stn 45) followed the M-M model better than the other ones, on which more variability was observed. A possible explanation for that is that at Stn 45 , hydrolysis was carried out by a dominance of microorganisms with identical or very similar kinetic properties, while at the more oligotrophic stations, hydrolysis was carried out by mixed microbial populations, which gave rise to different values of $V_{\mathrm{m}}$ and $K+S_{\mathrm{n}}$ depending on the range of substrate concentrations considered.

In addition to the great variability, $V_{\mathrm{m}}$ estimated by Li parameterisation (Table 2) is considerably lower than that expected, looking at the asymptote towards which APA apparently leans (Fig. 3a-c). When analysed in detail (Fig. $3 \mathrm{~d}-\mathrm{f}$ ), the 2 more oligotrophic stations showed an apparent initial saturation at low concentrations (Fig. 3d,e). The asymptote of this initial saturation is similar to the $V_{\mathrm{m}}$ estimated by Li parameterisation using all data (Fig. 3d,e, dashed line). In accordance with this observation, Bentzen et al. (1992) reported that the Li equation seems to give better fits at low substrate concentrations and, therefore, occa-

Table 1. Nutricline depth $\left(Z_{\text {nuti }}\right.$ upper limit of the nutricline layer), chl maximum depth $\left(Z_{\mathrm{CM}}\right)$, integrated $\mathrm{chl}$ (from 0 to $150 \mathrm{~m})$, and phosphate concentration at the chl maximum level, at the stations where kinetics analyses were carried out

\begin{tabular}{|lcrcc|}
\hline Stn & $\begin{array}{c}Z_{\text {nut }} \\
(\mathrm{m})\end{array}$ & $\begin{array}{c}Z_{\mathrm{CM}} \\
(\mathrm{m})\end{array}$ & $\begin{array}{c}\mathrm{Chl} \\
\left(\mathrm{mg} \mathrm{m}^{-2}\right)\end{array}$ & $\begin{array}{c}\mathrm{PO}_{4}{ }^{3-} \\
(\mu \mathrm{M})\end{array}$ \\
\hline 2 & 94 & 100 & 24 & 0.03 \\
102 & 77 & 72 & 31 & 0.07 \\
45 & 5 & 48 & 35 & 0.20 \\
\hline
\end{tabular}
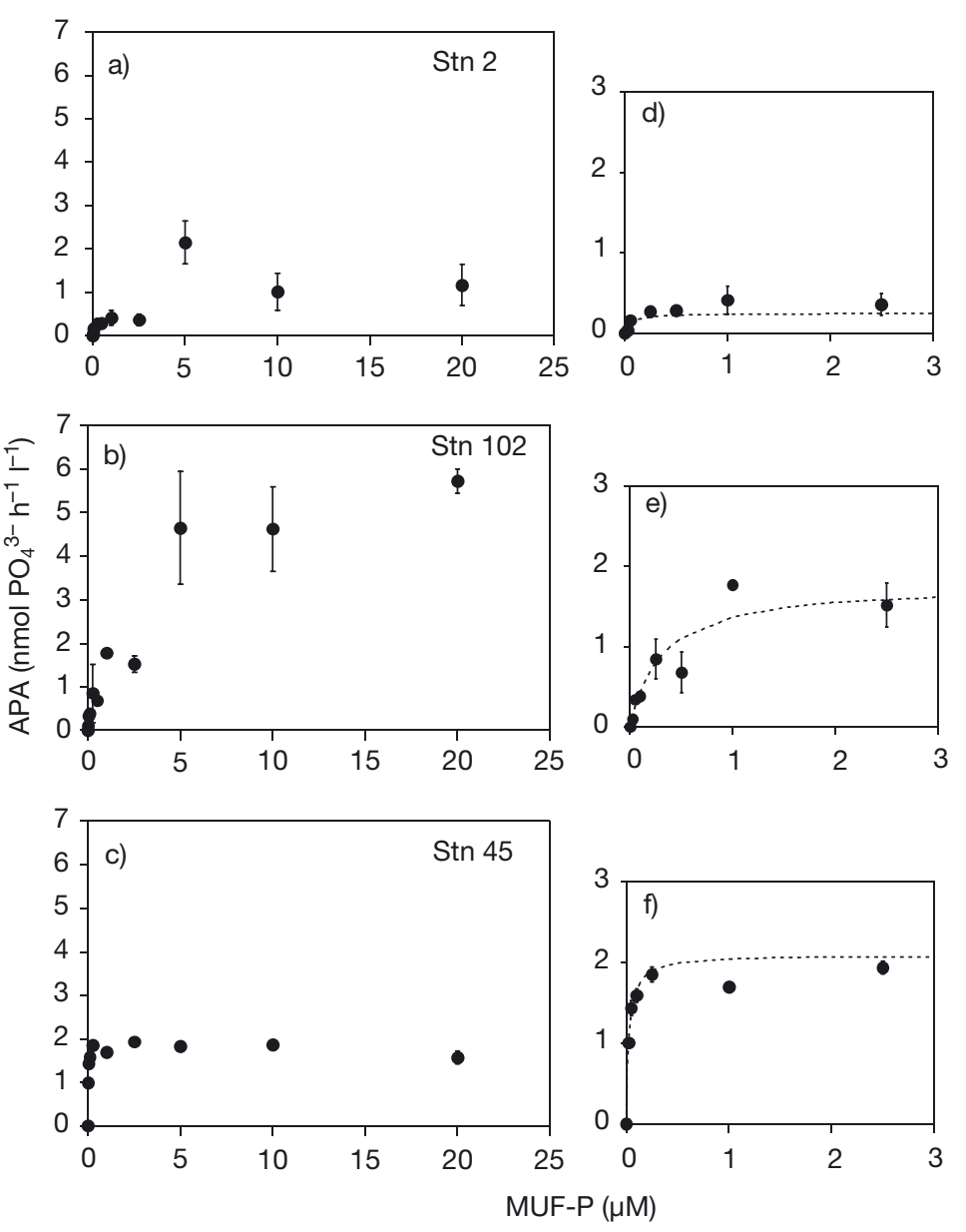

Fig. 3. Alkaline phosphatase activity (APA) as a function of substrate additions of methyl-umbelliferyl phosphate (MUF-P). (a) Stn 2; (b) Stn 102; (c) Stn 45. (d) to (f) are details of (a) to (c), respectively, at lower substrate concentrations. Dashed lines represent the fit by the Li parameterisation technique

sionally the whole-community $V_{\mathrm{m}}$ may be underestimated. Although we are concerned about that, ambient natural substrates for APA are usually at very low concentrations in marine environments $(\sim 50$ to $150 \mathrm{nM}$, Karl \& Yanagi 1997). This, together with the aforementioned better goodness-of-fit of the Li equa-

Table 2. Kinetic parameters (mean, SE in parentheses) estimated by the Li equation (Eq. 3). $V_{\mathrm{m}}$ is the maximum velocity, $K$ is the half saturation constant, $S_{\mathrm{n}}$ is the ambient concentration of substrates, and $T$ is the turnover time

\begin{tabular}{|lccc|}
\hline Stn & $V_{\mathrm{m}}\left(\mathrm{nM} \mathrm{h}^{-1}\right)$ & $K+S_{\mathrm{n}}(\mathrm{nM})$ & $T(\mathrm{~h})$ \\
\hline 2 & $0.25(0.08)$ & $56(30)$ & $224(140)$ \\
102 & $1.8(0.58)$ & $312(126)$ & $176(90)$ \\
45 & $2.1(0.09)$ & $27(3)$ & $13(1)$ \\
\hline
\end{tabular}


tion (see 'Materials and methods'), endorses the use of the Li-model for estimating kinetic parameters as the more appropriate.

The open water station (Stn 2) showed much lower values of $V_{m}$ than the others (Table 2), which showed no differences in $V_{\mathrm{m}}$ between them $(0.25,1.8$ and $2 \mathrm{nM}$ $\mathrm{h}^{-1}$, for Stns 2, 102 and 45, respectively). In contrast to that, $K+S_{\mathrm{n}}$ at Stn 102 was an order of magnitude higher than at Stns 2 and 45. The biological background for such higher values of $K+S_{\mathrm{n}}$ in the former may be either an increase in available substrates (increase in $S_{\mathrm{n}}$ ), or changes in the types of alkaline phosphatases (change in $K$ due to, e.g. changes in composition of natural assemblages).

The different kinetic parameters obtained at the 3 stations support the 3 types of kinetics of nutrient uptake stated by Azam \& Ammerman (1984) based on experimental evidence. They suggested that if natural substrate concentrations are very low in seawater, microorganisms will develop very high-affinity systems for efficient acquisition of these substrates, and low $K+S_{\mathrm{n}}$ and $V_{\mathrm{m}}$ would be expected. It is consistent with the oligotrophic character of Stn 2, where low values of both parameters were found.

However, if microorganisms were adapted to high microenvironmental substrate concentrations, one would predict high $K+S_{\mathrm{n}}$ and high $V_{\mathrm{m}}$, and this could be what it is happening at Stn 102, which showed high values of both parameters.

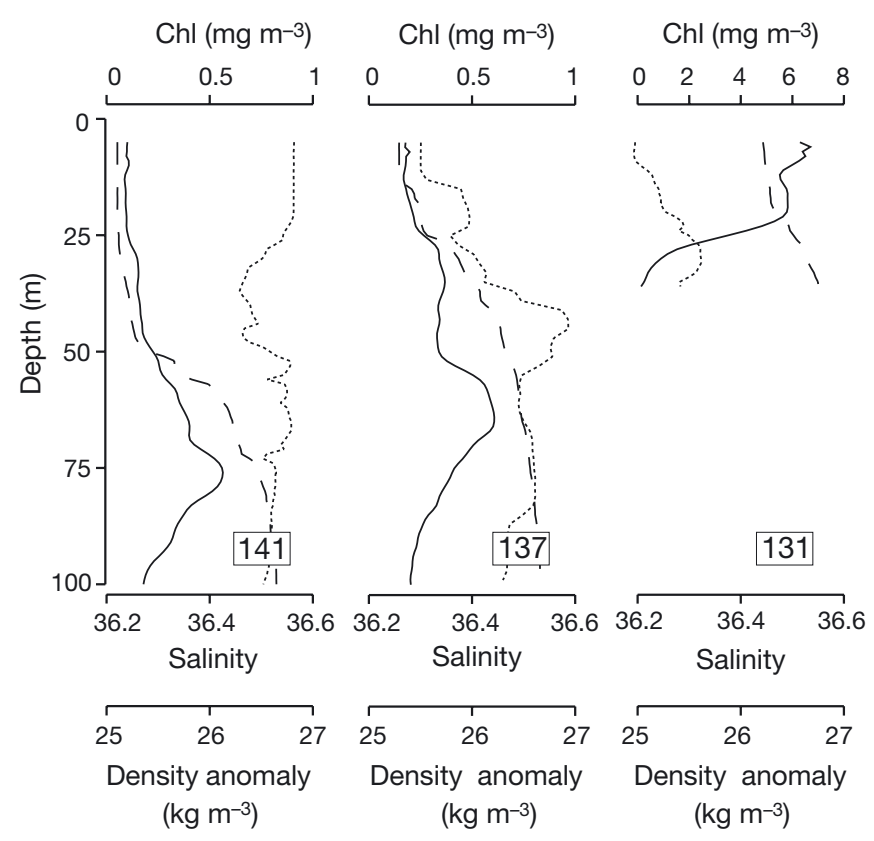

Fig. 4. Vertical profiles of chl (solid line), density anomaly (broken line) and salinity (dashed line) at stations of dissolved inorganic phosphorus (Pi) addition experiments: Stn 141 (Fuerteventura), Stn 137 (channel) and Stn 131 (upwelling)
At Stn 45, located in the cyclonic eddy near the upwelling area, a combination of low $K+S_{\mathrm{n}}$ and high $V_{\mathrm{m}}$ was obtained. This kinetic behaviour would provide metabolic flexibility in a heterogeneous and fluctuating environment, as reported by Ammerman \& Azam (1984).

There was a clear oligotrophic-eutrophic decreasing gradient in turnover time values $(224,176$ and $13 \mathrm{~h}$ for Stns 2, 102 and 45, respectively).

\section{APA inhibition by phosphate addition}

Inhibition experiments were carried out at 3 stations located in a straight line that arose from the African shelf to Fuerteventura (Fig. 1). Stn 131, located in the upwelling area, presented a strong eutrophic character, with very high chl values extending from surface down to $25 \mathrm{~m}$ depth, and low values of salinity in the whole water column (Fig. 4). At Stn 131, the nutricline was found up to $50 \mathrm{~m}$ shallower, and integrated chl was much higher than in the other 2 stations (Table 3). Stn 137 was located in the channel, and was affected by an upwelling filament, as derived from the salinity decrease in surface (Fig. 4) and as reported by Barton et al. (unpubl.). Chl showed relatively high values from $25 \mathrm{~m}$ depth (below the pycnocline), and reached a deep maximum around $60 \mathrm{~m}$ depth (Fig. 4). Stn 141 was situated near Fuerteventura Island and showed relatively constant values of salinity in the whole water column, and a deep chl maximum at ca. $75 \mathrm{~m}$ depth, at the base of the pycnocline (Fig. 4).

The response of APA to the addition of phosphate was different between the stations (Fig. 5). In the eutrophic station (Stn 131), APA was slightly affected by the amount of $\mathrm{Pi}$ added. Below the CM, APA showed a ca. $20 \%$ decrease at Pi addition $>0.5 \mu \mathrm{M}$, while at surface (coinciding with the chl maximum) no clear inhibition occurred.

In the channel station (Stn 137), inhibition was stronger than in the eutrophic station. APA at the CM was not affected by Pi additions less than $0.25 \mu \mathrm{M}$, but

Table 3. Nutricline depth $\left(Z_{\text {nut }}\right)$, chl maximum depth $\left(Z_{\mathrm{CM}}\right)$ and integrated chl (from 0 to $150 \mathrm{~m}$ ) at the stations where Pi addition experiments were carried out

\begin{tabular}{|lccc|}
\hline Stn & $Z_{\text {nut }}(\mathrm{m})$ & $Z_{\mathrm{CM}}(\mathrm{m})$ & $\mathrm{Chl}\left(\mathrm{mg} \mathrm{m}^{-2}\right)$ \\
\hline 131 & 3 & 6 & $132^{\mathrm{a}}$ \\
137 & 60 & 64 & 38 \\
141 & 50 & 75 & 28 \\
antegrated down to the cast depth $(35 \mathrm{~m})$ & \\
\hline
\end{tabular}


a)

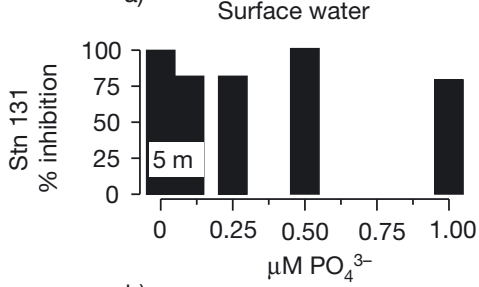

b)
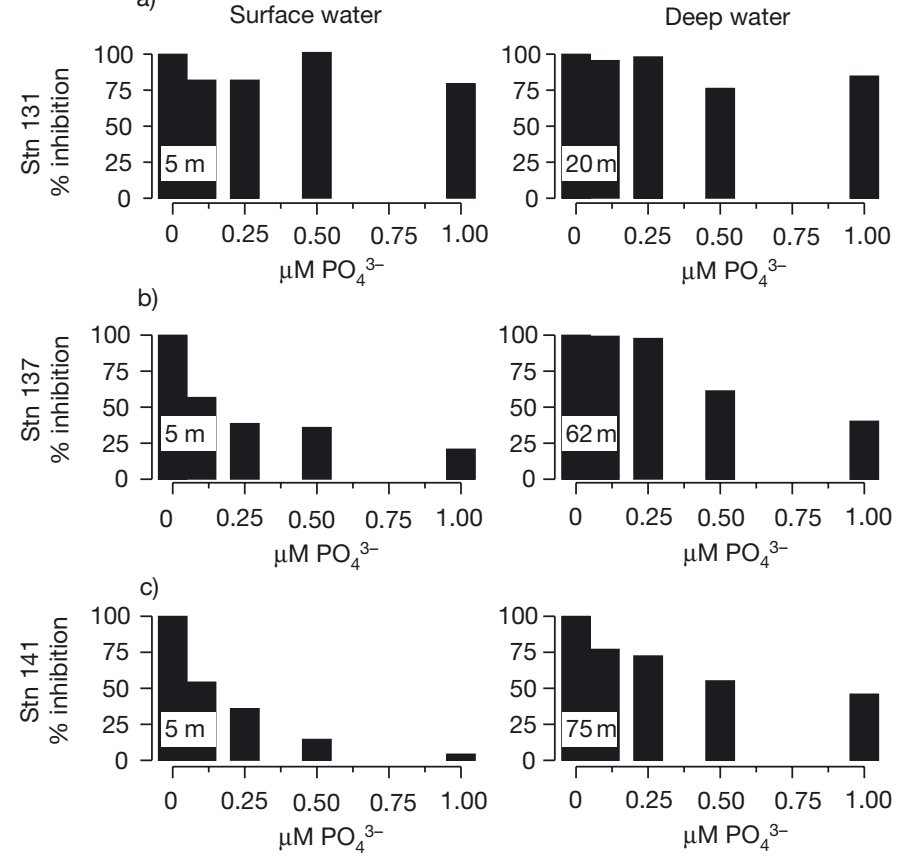

Fig. 5. \% inhibition of alkaline phosphatase activity (APA) by dissolved inorganic phosphorus (Pi) additions. (a) Stn 131 (upwelling), (b) Stn 137 (channel), (c) Stn 141 (Fuerteventura). Left panels: surface samples; right panels: deep samples (chl maximum [CM] of Stns 137 and 141); numbers in boxes are depths of sampling

it decreased steadily down to $50 \%$ of control when $1 \mu \mathrm{M}$ Pi was added. At the surface, APA was drastically affected by the addition of Pi. With only $0.1 \mu \mathrm{M}$ Pi added, APA was almost $50 \%$ inhibited, and as much as $80 \%$ inhibited with $1 \mu \mathrm{M}$ Pi added.

At the station near Fuerteventura (Stn 141), inhibition was also strong. At the CM, APA was inhibited by ca. 25 and $50 \%$ at 0.1 and $0.5 \mu \mathrm{M}$ Pi addition, respectively. At the surface, as in Stn 137, APA dropped to ca. $50 \%$ of its initial value, at only $0.1 \mu \mathrm{M}$ Pi added, and then inhibition was even more drastic and activity was $96 \%$ inhibited at $1 \mu \mathrm{M}$ Pi addition.
Inhibition of APA was therefore higher at a higher oligotrophic level, and was stronger at the surface than at the CM.

To study the reason for the different responses in inhibition experiments, we analysed in detail the characteristics of the 3 stations (Table 4).

Alkaline phosphatase activity increased towards inshore-upwelled waters. This trend also held for proteins, chl, PP and bacterial abundance. Overall, Pi concentration at the surface level was near the detection limit, whereas at the CM level it was also low, but increased towards the upwelling station. Nevertheless, total phosphorus concentration presented 4- to 6-fold higher values in the upwelling station at both surface and $\mathrm{CM}$ level, and the supply of phosphorus by vertical flux across the nutricline was 1 order of magnitude higher in the upwelling. Hence, low Pi values in the euphotic zone of the eutrophic station seem to be linked to surplus stored P (luxury consumption) in the microbial cells.

The increase in APA towards the more eutrophic stations was small compared to the increase in proteins, resulting in much higher APA per protein under oligotrophic conditions than in the upwelling (Table 4). When normalised by particulate phosphorus (APA/PP), the values increased steadily following the eutrophyoligotrophy gradient.

\section{DISCUSSION}

\section{Kinetic parameters}

In general, values of kinetic parameters found in the literature are higher than those found in this study. $V_{\mathrm{m}}$ was up to 1 to 2 orders of magnitude higher in Lake Plußsee (Chrôst \& Overbeck 1987), in the NW Mediterranean (Thingstad et al. 1998) and in the Gulf of Mexico (Ammerman \& Glover 2000). Nevertheless, Cotner et al. (1997) reported values of $V_{\mathrm{m}}$ in the same order as ours in the Sargasso Sea (1.39 to $\left.2.70 \mathrm{nM} \mathrm{h}^{-1}\right)$, and Hoppe \&

Table 4. Values of selected biological variables in the stations where dissolved inorganic phosphorus addition experiments were carried out. APA: alkaline phosphatase activity $\left(\mathrm{nM} \mathrm{h}^{-1}\right)$, Prt: proteins $\left(\mu \mathrm{g} \mathrm{l}^{-1}\right)$, chl: chlorophyll $\left(\mu \mathrm{l}^{-1}\right)$, BA: bacterial abundance (cell ml $\left.\mathrm{m}^{-1} \times 10^{6}\right)$, Pi: dissolved inorganic phosphorus $(\mu \mathrm{M})$, TP: total phosphorus $(\mu \mathrm{M})$, PP: particulate phosphorus (nM), APA:Prt ratio $\left(\mathrm{nmol} \mathrm{mg} \mathrm{mg}^{-1}\right)$, APA:PP $\left(\mathrm{nmol} \mu \mathrm{g}^{-1} \mathrm{~h}^{-1}\right)$ ratio, Pi flux: diffusive Pi fluxes across the nutricline $\left(\mathrm{mmol} \mathrm{P} \mathrm{m}^{-2} \mathrm{~h}^{-1}\right)$

\begin{tabular}{|lcccccccccccc|}
\hline & Stn & Depth $(\mathrm{m})$ & APA & Prt & Chl & BA & Pi & TP & PP & APA:Prt APA:PP & Pi flux \\
\hline Upwelling & 131 & $5(\mathrm{CM})$ & 0.36 & 643 & 6.58 & 2.34 & 0.04 & 0.40 & 379 & 0.57 & 1.0 & 0.032 \\
& & 20 & 0.29 & 587 & 7.26 & 1.58 & 0.16 & 0.50 & 117 & 0.50 & 2.5 & \\
Channel & 137 & 5 & 0.18 & 73 & 0.19 & 1.59 & 0.04 & 0.09 & 51 & 2.40 & 3.4 & 0.005 \\
& & $62(\mathrm{CM})$ & 0.10 & 47 & 0.46 & 1.20 & 0.06 & 0.10 & 37 & 2.16 & 2.8 & \\
Fuerteventura & 141 & 5 & 0.07 & 53 & 0.15 & 1.11 & 0.04 & 0.06 & 22 & 1.30 & 3.1 & 0.004 \\
& & & $75(\mathrm{CM})$ & 0.08 & 44 & 0.53 & 1.12 & 0.04 & 0.06 & 18 & 1.94 & 4.8 \\
\end{tabular}


Ullrich (1999) also obtained values close to ours in the euphotic zone of the Indian Ocean. A recent study carried out along a trans-Mediterranean transect, with a station located in the North African upwelling (Van Wambecke et al. 2002), reported values of $V_{\mathrm{m}}$ (0.62 to 12.6 and $1.1 \mathrm{nM} \mathrm{h}^{-1}$ in the upwelling station) and $K+S_{\mathrm{n}}$
( 0.076 to 0.206 and $0.848 \mu \mathrm{M}$ in the upwelling station) similar to the ones reported in our study.

Measurements of APA kinetics in seawater are scarce. Moreover, unfortunately, direct comparisons with literature values are not always possible, since substrates used to measure APA are not always the

Table 5. Kinetics of alkaline phosphatase activity (APA) in natural waters. Substrate used for APA measurement and range of substrate concentration for kinetic experiments; $V_{\mathrm{m}}$ : maximum velocity; $K^{\prime}: K+S_{\mathrm{n}}$ (see Table 2 legend for definitions); and sample fraction, in case of fractionated assays. p-NPP: p-nitrophenyl phosphate; MUF-P: 4-methylumbelliferyl phosphate; MFP: 3-methylfluorescein phosphate; ${ }^{32} \mathrm{P}-\mathrm{G} 6 \mathrm{P}:{ }^{32} \mathrm{P}$-glucose-6-phosphate

\begin{tabular}{|c|c|c|c|c|c|}
\hline $\begin{array}{l}\text { Concentration } \\
\text { range }(\mu \mathrm{M})\end{array}$ & $\begin{array}{c}V_{\mathrm{m}} \\
\left(\mathrm{nM} \mathrm{h}^{-1}\right)\end{array}$ & $\begin{array}{c}K^{\prime} \\
(\mu \mathrm{M})\end{array}$ & Fraction & Site & Source \\
\hline \multicolumn{6}{|l|}{ p-NPP } \\
\hline $50-800$ & $1000-20000$ & $150-420$ & $\begin{array}{l}\text { Total } \\
\text { (i.e. unfiltered water) }\end{array}$ & Freshwater systems & Heath (1986) \\
\hline $250-2000$ & - & - & Total & East Twin Lake & Boavida \& Heath (1988) \\
\hline- & - & $700-900$ & Particulate $(0.25-90 \mu \mathrm{m})$ & Mediterranean littoral & Gambin et al. (1999) \\
\hline $10-2100$ & $60-4560$ & $1-50$ & Total & Donghu Lake (China) & Yiyong \& Xinyu (1997) \\
\hline \multicolumn{6}{|l|}{ MUF-P } \\
\hline $0.5-40$ & 60 & - & Total & Baltic Sea & Hoppe (1983) \\
\hline $10-200$ & $7-430$ & $11.8-59.6$ & Total & Lake Plußsee & Chrost \& Overbeck (1987) \\
\hline- & $221-393$ & $0.52-2.61$ & Total & Lake Constance & Siuda \& Güde (1994) \\
\hline- & $212-319$ & $0.15-0.23$ & Total & Lake Schleinsee & \\
\hline $0-5$ & 37 & 0.23 & Bacterial $(0.2-1 \mu \mathrm{m})$ & $\begin{array}{l}\text { Lake Herrensee } \\
\text { (oligotrophic) }\end{array}$ & Hantke et al. (1996) \\
\hline $0-5$ & 84 & 0.23 & Algal $(>1 \mu \mathrm{m})$ & & \\
\hline $0-5$ & 153 & 0.85 & Dissolved $(<0.2 \mu \mathrm{m})$ & & \\
\hline $0-5$ & 66 & 0.15 & Bacterial $(0.2-1 \mu \mathrm{m})$ & $\begin{array}{l}\text { Lake Bräuhaussee } \\
\text { (mesotrophic) }\end{array}$ & \\
\hline $0-5$ & 79 & 0.44 & Algal $(>1 \mu \mathrm{m})$ & & \\
\hline $0-5$ & 135 & 0.77 & Dissolved $(<0.2 \mu \mathrm{m})$ & & \\
\hline $0-5$ & 71 & 0.14 & Bacterial $(0.2-1 \mu \mathrm{m})$ & $\begin{array}{l}\text { Lake Thaler See } \\
\text { (eutrophic) }\end{array}$ & \\
\hline $0-5$ & 293 & 0.40 & Algal (>1 $\mu \mathrm{m})$ & & \\
\hline $0-5$ & 248 & 0.47 & Dissolved $(<0.2 \mu \mathrm{m})$ & & \\
\hline $100,150^{\mathrm{a}}$ & $0.25-1.49$ & - & Total & Central Pacific & Koike \& Nagata (1997) \\
\hline- & $1.39-2.70$ & - & Total & Sargasso Sea & Cotner et al. (1997) \\
\hline $0.005-0.2$ & $23-33$ & $0.20-0.21$ & Total & $\begin{array}{l}\text { French Medi- } \\
\text { terranean coast }\end{array}$ & Thingstad et al. (1998) \\
\hline $250^{\mathrm{a}}$ & $2-3$ & - & Total & Indian Ocean & Hoppe \& Ullrich (1999) \\
\hline $0.01-10$ & $200-500$ & $0.2-0.3$ & Total & Gulf of Mexico & Ammerman \& Glover (2000) \\
\hline $1^{\mathrm{a}}$ & $3.4-119$ & - & Total & Florida Bay & Cotner et al. (2000) \\
\hline $0.025-1$ & $0.62-12.6$ & $0.076-0.21$ & Total & Mediterranean Sea & Van Wambeke et al. (2002) \\
\hline $0.025-1$ & 1.1 & 0.84 & Total & $\begin{array}{l}\text { North African } \\
\text { upwelling }\end{array}$ & \\
\hline $0.025-25$ & $0.25-2.1$ & $0.027-0.31$ & Total & NE Atlantic & This study \\
\hline \multicolumn{6}{|l|}{ MFP } \\
\hline- & 40 & 0.31 & Total & Chesapeake Bay & Taft et al. (1977) \\
\hline $0-3$ & 260 & 0.48 & Total & Lake Ontario & Pick (1987) \\
\hline $0-1$ & $6-171$ & $0.095-0.69$ & Total & $\begin{array}{l}\text { Sandsfjord (western } \\
\text { Norway) }\end{array}$ & Thingstad et al. (1993) \\
\hline \multirow[t]{2}{*}{$0-2$} & 22 & 0.42 & Particulate $(>0.45 \mu \mathrm{m})$ & Lake Minnesota & Rose \& Axler (1998) \\
\hline & 31 & 0.63 & Dissolved $(<0.45 \mu \mathrm{m})$ & & \\
\hline \multicolumn{6}{|l|}{${ }^{32} \mathbf{P}-G 6 P$} \\
\hline \multirow[t]{2}{*}{-} & 84 & 0.086 & Bacterial $(0.2-3 \mu \mathrm{m})$ & East Twin Lake & Hernández et al. (1996) \\
\hline & 456 & 0.38 & Algal (>3 $\mu \mathrm{m})$ & & \\
\hline
\end{tabular}


Table 6. Comparison between kinetic parameters (mean; SE in parentheses) estimated by the Li-parameterisation (Eq. 3) and the Michaelis-Menten (M-M) equation (Eq. 1). M-M fit was performed by KaleidaGraph software

\begin{tabular}{|lrccc|}
\hline Stn & $\begin{array}{c}V_{\mathrm{m}(\mathrm{Li})} \\
\left(\mathrm{nM} \mathrm{h}^{-1}\right)\end{array}$ & $\begin{array}{c}V_{\mathrm{m}(\mathrm{M}-\mathrm{M})} \\
\left(\mathrm{nM} \mathrm{h} \mathrm{h}^{-1}\right)\end{array}$ & $\begin{array}{c}K^{\prime}(\mathrm{Li}) \\
(\mathrm{nM})\end{array}$ & $\begin{array}{c}K_{\mathrm{m}(\mathrm{M}-\mathrm{M})} \\
(\mathrm{nM})\end{array}$ \\
\hline 2 & $0.25(0.08)$ & $1.22(0.31)$ & $56(30)$ & $1138(1262)$ \\
102 & $1.8(0.58)$ & $4.77(0.65)$ & $312(126)$ & $1850(1055)$ \\
45 & $2.1(0.09)$ & $1.80(0.06)$ & $27(3)$ & $17(4)$ \\
& & & & \\
\hline
\end{tabular}

same, the range of substrate concentrations often differ, and sometimes data from size-fractionated assays instead of from the whole sample are shown (Table 5). Generally, when p-NPP (p-nitrophenyl phosphate instead of MUF-P substrate is used, kinetic parameters reported in the literature reach much higher values (from 1 to 2 orders of magnitude), but it also depends largely on the range of substrates used for the assays. Garcia et al. (1997) used equal concentrations of both p-NPP and MUF-P (3 to $1000 \mu \mathrm{M}$ ) to study phosphatase kinetics in a Phaeodactylum tricornutum culture, and obtained high values of $V_{\mathrm{m}}$ and $K^{\prime}$ for both substrates, although $K^{\prime}$ for p-NPP was slightly higher (8.2 and $3.1 \mu \mathrm{M}$ for $\mathrm{p}-\mathrm{NPP}$ and MUF-P, respectively). Chrôst \& Overbeck (1987) also reported very high $K^{\prime}$ values (11.8 to 59.6 $\mu \mathrm{M}$ ) in Lake Plußsee using MUF-P as substrate (Table 5). These values were up to 3 orders of magnitude higher than those reported in most of the studies that have been carried out with MUF-P, but these high $K^{\prime}$ values are probably related to the higher range of substrate concentrations used in both works. As we mentioned above (see 'Materials and methods'), for calculation of $V_{\mathrm{m}}$ and $K^{\prime}$ in this study we decided to use the Li-parameterisation that gives a better fit at low substrate concentrations, which are likely to be encountered in the area of study. Nevertheless, if we calculate them using a direct non-linear fit to the M-M equation (Eq. 1, see 'Materials and methods'), results obtained are quite different (Table 6). Except for Stn 45, where results are in the same range as those obtained by Li-parameterisation, in the other 2 stations estimates of $V_{\mathrm{m}}$ and $K^{\prime}$ are much higher using the M-M equation. $V_{\mathrm{m}(\mathrm{M}-\mathrm{M})}$ values are close to the asymptotes towards which $V$ tends, at high values of substrate (Fig. 3a-c), whereas $K_{(\mathrm{M}-\mathrm{M})}$ in Stns 2 and 102 reached values up to 1 or 2 orders of magnitude higher than those estimated by the Li parameterisation, and even higher than most of the data reported by other authors (Table 5).

Wright-Hobbie linearisation (Eq. 4, see 'Materials and methods') was also performed to study how kinetic patterns varied over the substrate range used. The resultant non-linear plots in the 2 oligotrophic stations
Table 7. Kinetic parameters (mean; SE in parentheses) obtained from Wright-Hobbie plots. $S_{\mathrm{a}}$ is the range of substrate added, $V_{\mathrm{m}}$ is the maximum velocity, $K^{\prime}$ is the sum $K+S_{\mathrm{n}}$ (see Table 2 legend for definitions)

\begin{tabular}{|lccc|}
\hline Stn & $S_{\mathrm{a}}(\mu \mathrm{M})$ & $V_{\mathrm{m}}\left(\mathrm{nM} \mathrm{h}^{-1}\right)$ & $K^{\prime}(\mathrm{nM})$ \\
\hline 2 & $0-0.5$ & $0.36(0.07)$ & $117(86)$ \\
& $1-25$ & $1.09(0.24)$ & $421(196)$ \\
102 & $0-2.5$ & $1.72(0.19)$ & $379(97)$ \\
& $2.5-25$ & $6.49(1.27)$ & $3410(606)$ \\
45 & $0-25$ & $1.71(0.05)$ & $40(23)$ \\
& & & \\
\hline
\end{tabular}

(Stns 2 and 102) revealed a multiphasic pattern in the kinetic curve, while the eutrophic station exhibited a single kinetic pattern over the range of MUF-P considered (data not shown). Kinetic parameters computed from these plots are shown in Table 7. Considering only the lower range of substrate concentration, $V_{\mathrm{m}}$ estimates obtained by Wright-Hobbie linearisation are very similar to those obtained by the Li model, whereas $K^{\prime}$ estimates are in the same order of magnitude but generally higher. However, in the upper range of MUF-P concentration, kinetic parameters are in the same order of magnitude of those estimated with the Michaelis-Menten equation.

The coexistence of high-affinity and low-affinity systems either in individual populations or due to heterogeneous natural assemblages, which give rise to different values of $V_{\mathrm{m}}$ and $K^{\prime}$ depending on the range of substrate considered, possibly reflects adaptation to varied substrate concentration regimes (Azam \& Hodson 1981). Garcia et al. (1997) also obtained multiphasic kinetics of APA for both p-NPP and MUF-P in their study with Phaeodactylum tricornutum.

Therefore, in order to study the contribution of AP to phosphate regeneration in aquatic environments, the fitting technique is important, and it is also important to carry out kinetic experiments over the range of naturally occurring substrate concentrations, because otherwise hydrolysis rates may be underestimated. In this sense Hantke et al. (1996) pointed out that Heath (1986) and Boavida \& Heath (1988) concluded that AP only satisfied $1 \%$ of P planktonic demand as a consequence of the high substrate concentrations used in their study, which resulted in very high $K^{\prime}$, whereas AP would provide the main part of $\mathrm{P}$ for phosphate uptake in Heath's (1986) study using $K^{\prime}$ 's in the same order of magnitude as those obtained by Hantke et al. (1996). These $K^{\prime}$ s are in the same range that those obtained in all the studies reflected in Table 5, in which kinetics were performed at lower levels of substrate.

There is evidence in the bibliography of distinct patterns of ectoenzyme kinetics in different trophic environments (Hoppe 1983, Rath et al. 1993, Hantke et 
al. 1996). Consistent with the results obtained in this study (i.e. lower $V_{\mathrm{m}}$ at the most oligotrophic station), Hoppe (1983) concluded that $V_{\mathrm{m}}$ decreased more or less regularly as one approached the open sea in a study in 2 eutrophied Baltic Sea fjords and the adjacent offshore waters. However Van Wambeke et al. (2002) obtained greater values of $V_{\mathrm{m}}$ towards more oligotrophic waters.

Phytoplankton-associated APA has been used as an indicator of phosphorus limitation because it is synthesised at low levels of P availability (Petterson 1980), repressed when $\mathrm{P}$ becomes available (Perry 1972, Elser \& Kimell 1986), and it has been shown to be inversely related to extracellular and intracellular P concentrations. Nevertheless, in natural systems it is difficult to distinguish among phosphatases produced by other organisms such as zooplankton (Boavida \& Heath 1984, Jansson et al. 1988) or bacterioplankton (Cembella et al. 1984, Jansson et al. 1988), and there may also be a background level of constitutive enzymes. Therefore, results of using APA as a P-deficiency index in ecological studies have not always been satisfactory (Pick 1987, Jamet et al. 1997).

However, evidence of APA being repressed under high Pi concentrations in aquatic ecosystems in the literature is frequent. Chrôst \& Overbeck (1987), in lake Plußsee, observed that APA significantly decreased when the ambient phosphate concentrations were higher than $0.5 \mu \mathrm{M}$. Moreover, Ammerman \& Azam (1991) reported that AP activity was usually low and sometimes unmeasurable in the P-rich waters around New York, and Nausch (1998), in the Baltic Sea, observed a significant decrease in APA at ambient phosphate concentrations higher than $1 \mu \mathrm{M}$.

Together, these observations lead to workers' attempts to use APA as a P-deficient index.

It is therefore somewhat surprising that we have obtained the highest hydrolysis rates (the lowest turnover times) and the lowest $K+S_{\mathrm{n}}$ at the most eutrophic station, where the highest Pi concentrations were found and, therefore, the lowest hydrolysis and lowest MUF-substrate affinity were expected.

Nevertheless, Hoppe (1983) also found a very strong increase in APA towards the eutrophic part of a fjord, and Hantke et al. (1996) also reported an increase in hydrolysis rates with higher eutrophic level. Likewise, Kobori \& Taga (1979) measured high APA at high inorganic phosphorus levels in Tokyo Bay.

High hydrolysis rates in eutrophic habitats may be explained by larger abundance of organisms in these areas, which may lead to much shorter turnover times.

But why was APA highly efficient in the eutrophic station when Pi concentrations were likely sufficient for the plankton requirement? Chrôst \& Overbeck (1987) suggested that bacteria might produce APA to hydro- lyse organophosphoric compounds, but probably utilised the organic moiety as an organic carbon source.

Moreover, it has been observed that bacterial AP has higher substrate affinity (lower $K^{\prime}$ ) than algal AP (Chrôst \& Overbeck 1987, Hantke et al. 1996, Hernández et al. 1996), and Chrôst \& Overbeck (1987) found that, while algal $K+S_{\mathrm{n}}$ increased at increasing additions of $\mathrm{Pi}$, bacterial $K+S_{\mathrm{n}}$ remained near unchanged (i.e. bacterial phosphatases were not Pi-inhibited). That suggests that the low $K+S_{\mathrm{n}}$ values found at the eutrophic station may be related to bacteria instead of to phytoplankton.

\section{Effect of phosphate in APA}

It is well documented that the synthesis of many ectoenzymes produced by aquatic microorganisms is inhibited (or even repressed) by the end product that is derived from the substrate and accumulates in the cell or in the surrounding environment.

There are several studies of inhibition of APA by the addition of phosphate, or the regulatory function of phosphate on APA.

Rivkin \& Swift (1979), in a study with the oceanic dinoflagellate Pyrocystis noctiluca, obtained notable reduction in enzyme activity after the addition of

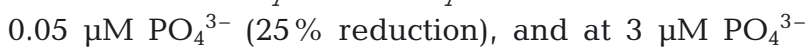
added APA was undetectable within $2 \mathrm{~h}$.

In culture studies with a red tide dinoflagellate, Vargo \& Shanley (1985) found that after $30 \mathrm{~min}$ of incubation with $20 \mu \mathrm{M} \mathrm{Pi}$, APA had dropped to $28 \%$ of its initial value, whereas Pick (1987) found that phosphate additions greater than those observed under natural conditions in Lake Ontario $(1 \mu \mathrm{M})$ were needed to inhibit APA to $50 \%$ of its initial level within $18 \mathrm{~h}$. Rose \& Axler (1998) in lake superior have several data sets showing APA reductions of $>50 \%$ after 3 to $4 \mathrm{~d}$ in response to additions of $0.32 \mu \mathrm{M}$. Moreover, Ammerman \& Azam (1991) showed that APA was $75 \%$ inhibited by $0.1 \mathrm{mM}$ Pi.

From these studies, it may be concluded that addition of Pi to seawater causes a loss of APA and a repression of APA synthesis at certain Pi concentrations.

In this study, APA inhibition by Pi became stronger towards surface and oligotrophic waters.

In upwelling areas, the continuous pumping of phosphate into the euphotic zone promotes nutrient luxury consumption by phytoplankton cells that store $\mathrm{P}$ in an inorganic form (surplus P) (Becerra 2001). It has been observed that the amount of surplus P stored in algal cells is inversely proportional to the specific activity of APA of the algal size fraction (Gage \& Gorham 1985, Chrôst \& Overbeck 1987). Thus, both the surplus P and 
the higher phosphate concentration in the upwelling waters could explain the lower APA:protein and APA:PP ratios in the eutrophic station. The higher hydrolysis rates in the nutrient-rich station could therefore be a result of a larger abundance of organisms (i.e. many cells with low activity per cell).

However, we cannot reject the possibility that a few organisms were not Pi-inhibited, presenting high activity per cell. Kuo \& Blumenthal (1961) demonstrated that phosphate-repressible APA is not a common property of bacteria. As phytoplankton APA is likely repressed or deactivated in Pi-rich waters, the APA we encountered in the upwelling was probably related to the bacterial fraction.

The near lack of inhibition in the upwelling station, compared to the oligotrophic ones, supports the hypothesis of APA being of bacterial origin in the upwelled waters. Another fact that supports this suggestion is the low $K+S_{\text {n }}$ obtained in the kinetic experiment carried out at a nutrient-rich station, as we mentioned above.

The determination of APA in seawater involves the measurement of both induced and constitutive enzymes. Due to the repressible properties of APA by $\mathrm{Pi}$, constitutive enzymes may be especially important in Pi-rich habitats (Forsberg \& Cheng 1980). However, Wilkins (1972) demonstrated that bacterial APA was induced in excess of Pi by starvation for nucleotides. Hence, bacterial APA in the upwelling station may be either constitutive or produced in response to insufficient easily assimilable organic carbon, or both.

Linear regression of APA versus bacterial biomass in eutrophic waters showed that bacterial biomass explained a high percentage of the APA observed $\left(\mathrm{r}^{2}=\right.$ $0.71, p=0.002, n=10$, S-plus software), while chl concentration was not correlated with APA $\left(\mathrm{r}^{2}=0.18\right.$, $\mathrm{p}=0.2$ ).

Sobecky et al. (1996) studied the impact of the introduction in natural assemblages of an engineered bacterium that constitutively expressed high levels of alkaline phosphatase. The overproduction of APA affected the rate of phosphate formation, which resulted in higher phosphate concentrations in the medium. This led to an increase in phytoplankton biomass (up to 14-fold) in both the oligotrophic and more eutrophic waters tested.

Generally, the ambient pool of labile DOC has a higher concentration in eutrophic than in oligotrophic systems (Søndergaard \& Middelboe 1995). Thingstad et al. (1997) modelled the interactions of bacteria, phytoplankton and bacterivorous protozoa to study the balance between DOC production and consumption along a gradient from oligotrophy to eutrophy. One solution of the model led them to suggest that a shift to C-limited bacteria at a higher eutrophic level would depend on which processes increase most with enrichment, DOC production by phytoplankton or bacterial consumption.

Most DOP compounds must be dephosphorylated before the $\mathrm{C}$ moiety can be taken up into the cell (Bengis-Garber \& Kushner 1982, Ammerman \& Azam 1991, Hernández et al. 1996), and hydrolysis is usually the rate-limiting step for the incorporation of organic substrates (Hoppe \& Ullrich 1999). Some authors have made experiments of competitive inhibition of APA by various organic substrates (Pick 1987, Cotner \& Wetzel 1991, Hernández et al. 1996). However, these substrates are almost always phosphorylated and, thus, it is difficult to assess whether there will be inhibition of APA by addition of the organic moiety, which could highlight whether bacteria uses their AP to obtain easily assimilable carbon. Nevertheless, Cotner \& Wetzel (1991) observed inhibition on hydrolysis of ATP (by APA and 5-PN) after addition of adenine.

In a study on the responses of bacterioplankton and phytoplankton to organic carbon and inorganic nutrient additions in contrasting oceanic ecosystems, Caron et al. (2000) found that in the nutrient-rich waters of Georges Bank, bacterial production increased in response to glucose additions, while in the nutrient poor waters of the Sargasso Sea, bacterial production increased with inorganic nutrient additions, and showed no response to glucose additions. Kirchman et al. (2000) also found that glucose amendments stimulated bacteria production by as much as 10 -fold in the California upwelling regime. This seems to be evidence for the occurrence of C-limited bacteria in nutrient-rich waters.

Recently, Van Wambeke et al. (2002) also found evidence of stimulation of bacterial production by organic carbon addition (glucose) to samples from the North African upwelling, whereas at stations located in the oligotrophic Eastern Mediterranean, glucose amendments had no effect on bacterial production.

Greater inhibition by phosphate additions in the oligotrophic stations probably reflects the fact that phytoplankton APA increased towards oligotrophy. At the CM level, inhibition was always lower, probably because CM was usually occurring in the upper part of the nutricline, where ambient phosphate concentration and, thus, intracellular phosphorus were higher.

The general trend emerging from the aforementioned studies and the present work is that $\mathrm{C}$-deficient bacteria in eutrophic waters present high-affinity APA to get easily assimilable carbon and, thus, this APA is not affected by high concentrations of phosphate, whereas in oligotrophic waters AP is involved mainly in supplying phosphorus for phytoplankton production, and therefore inhibited by phosphate amendments. 
Acknowledgements. This work was funded through the European Union (project CANIGO, MAS3.CT96-0060). We thank the officers and crew of the BIO 'Hespérides', as well as the staff of the UTM (CSIC) for their invaluable help at sea. Nutrient analyses on the autoanalyzer were carried out by J. Escánez. M.S. has also been supported by a FPI/FSE fellowship from the Instituto Español de Oceanografía during the elaboration of the manuscript. She acknowledges T. Ramírez and D. Cortés for their help and supervision. We also wish to thank the 4 anonymous referees that helped us to improve the paper.

\section{LITERATURE CITED}

Ammerman JW, Azam F (1985) Bacterial 5'-nucleotidase in aquatic ecosystems: a novel mechanism of phosphorus regeneration. Science 227:1338-1340

Ammerman JW, Azam F (1991) Bacterial 5'-nucleotidase activity in estuarine and coastal marine waters: characterization of enzyme activity. Limnol Oceanogr 36: $1427-1436$

Ammerman JW, Glover WB (2000) Continuous underway measurement of microbial ectoenzyme activities in aquatic ecosystems. Mar Ecol Prog Ser 201:1-12

Azam F, Ammerman JW (1984) Cycling of organic matter by bacterioplankton in pelagic marine ecosystems: microenvironmental considerations. In: Fasham MJ (ed) Flows of energy and materials in marine ecosystems. Plenum Press, New York, p 345-360

Azam F, Hodson RE (1981) Multiphasic kinetics for D-glucose uptake by assemblages of natural marine bacteria. Mar Ecol Prog Ser 6:213-222

Becerra J (2001) Fósforo y abundancia fitoplanctónica en el atlántico oriental (transecto $\mathrm{AMT6}: 33^{\circ} \mathrm{S}-42^{\circ} \mathrm{N}$ ). MS thesis, University of Málaga

Bengis-Garber C, Kushner DJ (1982) Role of membranebound $5^{\prime}$-nucleotidase in nucleotide uptake by the moderate halophile Vibrio costicola. J Bacteriol 149:808-815

Bentzen E, Taylor WD, Millard ES (1992) The importance of dissolved organic phosphorus to phosphorus uptake by limnetic plankton. Limnol Oceanogr 37:217-231

Boavida MJ, Heath RT (1984) Are the phosphatases released by Daphnia magna components of its food? Limnol Oceanogr 29:641-645

Boavida MJ, Heath RT (1988) Is alkaline phosphatase always important in phosphate regeneration? Arch Hydrobiol 111:507-518

Cañellas M, Agustí S, Duarte CM (2000) Latitudinal variability in phosphate uptake in the Central Atlantic. Mar Ecol Prog Ser 194:283-294

Caron DA, Lin Lim E, Sanders RW, Dennett MR, Berninger UG (2000) Responses of bacterioplankton and phytoplankton to organic carbon and inorganic nutrient additions in contrasting oceanic ecosystems. Aquat Microb Ecol 22:175-184

Cembella AD, Antia NJ, Harrison PJ (1984) The utilization of inorganic and organic phosphorus compounds as nutrients by eukariotic microalgae: a multidisciplinary perspective. Part I. CRC Crit Rev Microbiol 10:317-391

Chrôst RJ (1990) Microbial ectoenzymes in aquatic environments. In: Overbeck J, Chrôst RJ (eds) Aquatic microbial ecology: biochemical and molecular approaches. Springer-Verlag, New York, p 47-78

Chrôst RJ, Overbeck J (1987) Kinetics of alkaline phosphatase activity and phosphorus availability for phytoplankton and bacterioplankton in Lake Plußsee (North German eutrophic lake). Microb Ecol 13:229-248

Cotner JB Jr, Wetzel RG (1991) 5'-nucleotidase activity in a eutrophic lake and a oligotrophic lake. Appl Environ Microbiol 57:1306-1312

Cotner JB, Ammerman JW, Peele ER, Bentzen E (1997) Phosphorus-limited bacterioplankton growth in the Sargasso Sea. Aquat Microb Ecol 13:141-149

Cotner JB, Sada RH, Bootsma H, Johengen T, Cavaletto JF, Gardner WS (2000) Nutrient limitation of heterotrophic bacteria in Florida Bay. Estuaries 23:611-620

Elser JJ, Kimmel BL (1986) Alteration of phytoplankton phosphorus status during enrichment experiments: implications for interpreting nutrient enrichment bioassay results. Hydrobiologia 133:217-222

Fernández JA, Niell FX, Lucena J (1985) A rapid and sensitive automated determination of phosphate in natural waters. Limnol Oceanogr 30:227-230

Forsberg CW, Cheng KJ (1980) The constitutive nature of alkaline phosphatase in rumen bacteria. Can J Microbiol 26:268-272

Gage M, Gorham EG (1985) Alkaline phosphatase activity and cellular phosphorus as an index of the phosphorus status of phytoplankton in Minnesota lakes. Freshw Biol 15:227-333

Gambin F, Bogé G, Jamet D (1999) Alkaline phosphatase in a littoral Mediterranean marine ecosystem: role of the main plankton size classes. Mar Environ Res 47:441-456

García Ruiz R, Hernández I, Lucena J, Niell FX (1997) Preliminary studies on the significance of alkaline phosphatase activity in the diatom Phaeodactylum tricornutum Bohlin. Sci Mar 61:517-525

Hantke B, Fleischer P, Domany I, Koch M, Pleß P, Wiendl M, Melzer A (1996) P-release from DOP by phosphatase activity in comparison to $\mathrm{P}$ excretion by zooplankton. Studies in hardwater lakes of different trophic level. Hydrobiologia 317:151-162

Heath RT (1986) Dissolved organic phosphorus compounds: do they satisfy planktonic phosphate demand in summer? Can J Fish Aquat Sci 43:343-350

Hernández I, Hwang SJ, Heath RT (1996) Measurement of phosphomonoesterase activity with a radiolabelled glucose-6-phosphate. Role in the phosphorus requirement of phytoplankton and bacterioplankton in a temperate mesotrophic lake. Arch Hydrobiol 137:265-280

Hino S (1988) Fluctuation of algal alkaline phosphatase activity and the possible mechanisms of hydrolysis of dissolved organic phosphorus in Lake Barato. Hydrobiologia 157: $77-84$

Holm-Hansen O, Lorenzen JC, Holmes RW, Strickland JDH (1965) Fluorimetric determination of chlorophyll. J Cons Int Explor Mer 30:3-15

Hoppe HG (1983) Significance of exoenzymatic activities in the ecology of brackish water: measurements by means of methylumbelliferyl-substrates. Mar Ecol Prog Ser 11: 299-308

Hoppe HG, Ullrich S (1999) Profiles of ectoenzymes in the Indian Ocean: phenomena of phosphatase activity in the mesopelagic zone. Aquat Microb Ecol 19:139-148

Jamet D, Amblard C, Devaux J (1997) Seasonal changes in alkaline phosphatase activity of bacteria and microalgae in Lake Pavin (Massif Central, France). Hydrobiologia 347:185-195

Jansson M, Olsson H, Petterson K (1988) Phosphatases: origin, characteristics and function in lakes. Hydrobiologia 170:157-175

Karl DM, Yanagi K (1997) Partial characterization of the dissolved organic phosphorus pool in the oligotrophic 
North Pacific Ocean. Limnol Oceanogr 42:1398-1405

Kirchman DL, Meon B, Cottrell MT, Hutchins DA, Weeks D, Bruland KW (2000) Carbon versus iron limitation of bacterial growth in the California upwelling regime. Limnol Oceanogr 45:1681-1688

Kobori H, Taga N (1979) Phosphatase activity and its role in the mineralization of organic phosphorus in coastal sea water. J Exp Mar Biol Ecol 36:23-39

Koike I, Nagata T (1997) High potential activity of extracellular alkaline phosphatase in deep waters of the central Pacific. Deep-Sea Res II 44:2283-2294

Kuo MH, Blumenthal, HJ (1961) Absence of phosphatase repression by inorganic phosphate in some micro-organisms. Nature 190:29-31

Lee S, Fuhrman JA (1987) Relationships between biovolume and biomass of naturally derived marine bacterioplankton. Appl Environ Microbiol 53:1298-1303

Li WKW (1983) Consideration of errors in estimating kinetic parameters based on Michaelis-Menten formalism in microbial ecology. Limnol Oceanogr 28:185-190

Linden PF (1971) Salt fingers in the presence of grid-generated turbulence. J Fluid Mechanic 49:611-624

Lowry PH, Rosebrough NJ, Farr AL, Randall RJ (1951) Protein measurement with a Folin phenol reagent. J Biol Chem 193:265-275

Martinez J, Smith DC, Steward GF, Azam F (1996) Variability in ectohydrolytic enzyme activities of pelagic marine bacteria and its significance for substrate processing in the sea. Aquat Microb Ecol 10:223-230

Nausch M (1998) Alkaline phosphatase activities and the relationship to inorganic phosphate in the Pomeranian Bight (southern Baltic Sea). Aquat Microb Ecol 16:87-94

Oakey NS (1982) Determination of the rate of dissipation of turbulent energy from simultaneous temperature and velocity shear microstructure measurements. J Physical Oceanogr 12:256-271

Oakey NS, Elliot JA (1982) Dissipation within the surface mixed layer. J Physical Oceanogr 12:171-185

Perry MJ (1972) Alkaline phosphatase activity in subtropical central North Pacific waters using a sensitive fluorometric method. Mar Biol 15:113-119

Peterson GL (1977) A simplification of the protein assay method of Lowry et al. which is more generally applicable. Anal Biochem 83:346-356

Petterson K (1980) Alkaline phosphatase activity and algal surplus phosphorus as phosphorus deficiency indicators in Lake Erken. Arch Hydrobiol 89:54-87

Pick FR (1987) Interpretations of alkaline phosphatase activity in Lake Ontario. Can J Fish Aquat Sci 44:2087-2094

Rath J, Schiller C, Herndl GJ (1993) Ectoenzymatic activity and bacterial dynamics along a trophic gradient in the Caribbean Sea. Mar Ecol Prog Ser 102:89-96

Rivkin RB, Anderson MR (1997) Inorganic nutrient limitation of oceanic bacterioplankton. Limnol Oceanogr 42:730-740

Rivkin R, Swift E (1979) Diel and vertical patterns of alkaline

Editorial responsibility: Otto Kinne (Editor),

Oldendorf/Luhe, Germany phosphatase activity in the oceanic dinoflagellate Pyrocystis noctiluca. Limnol Oceanogr 24:107-116

Rose C, Axler RP (1998) Uses of alkaline phosphatase activity in evaluating phytoplankton community phosphorus deficiency. Hydrobiologia 361:145-156

Siuda W, Güde H (1994) A comparative study on 5'-nucleotidase (5'-nase) and alkaline phosphatase (APA) activities in two lakes. Arch Hydrobiol 131:211-229

Sobecky PA, Schell MA, Moran MA, Hodson RE (1996) Impact of a genetically engineered bacterium with enhanced alkaline phosphatase activity on marine phytoplankton communities. Appl Environ Microbiol 62:6-12

Sommers LE, Nelson DW (1972) Determination of total phosphorus by a rapid perchloric acid procedure. Soil Sci Soc Am Proc 36:902-904

Søndergaard M, Middelboe M (1995) A cross-system analysis of labile dissolved organic carbon. Mar Ecol Prog Ser 118: 283-294

Strickland JDH, Solorzano L (1966) Determination of hydrolysable phosphate and phosphomonoesterase activity in seawater. In: Barnes $\mathrm{H}$ (ed) Some contemporary studies in marine science. George Allen \& Unwin, London, p 665-674

Taft JL, Loftus ME, Taylor WR (1977) Phosphate uptake from phosphomonoesters by phytoplankton in the Chesapeake Bay. Limnol Oceanogr 22:1012-1021

Thingstad TF, Skjoldal EF, Bohne RA (1993) Phosphorus cycling and algal-bacterial competition in Sandsfjord, western Norway. Mar Ecol Prog Ser 99:239-259

Thingstad TF, Hagström ̊̊, Rassoulzadegan F (1997) Accumulation of degradable DOC in surface waters: is it caused by a malfunctioning microbial loop. Limnol Oceanogr 42:398-404

Thingstad TF, Zweifel UL, Rassoulzadegan F (1998) P limitation of heterotrophic bacteria and phytoplankton in the northwest Mediterranean. Limnol Oceanogr 43:88-94

Van Wambeke F, Christaki U, Giannakourou A, Moutin T, Souvemerzoglou K (2002) Longitudinal and vertical trends of bacterial limitation by phosphorus and carbon in the Mediterranean Sea. Microb Ecol 43:119-133

Vargo GA, Shanley E (1985) Alkaline phosphatase activity in the red-tide dinoflagellate, Ptychodiscus brevis. PSZN I: Mar Ecol 6:251-264

Wilkins AS (1972) Physiological factors in the regulation of alkaline phosphatase synthesis in Escherichia coli. J Bacteriol 110:616-623

Wright RT, Hobbie JE (1966) Use of glucose and acetate by bacteria and algae in aquatic ecosystems. Ecology 47: $447-464$

Yiyong Z, Xinyu Z (1997) Seasonal variation in kinetic parameters of alkaline phosphatase activity in a shallow chinese freshwater lake (Donghu Lake). Wat Res 31:1232-1235

Zohary T, Robarts RD (1998) Experimental study of microbial $\mathrm{P}$ limitation in the eastern Mediterranean. Limnol Oceanogr 43:387-395

Submitted: April 4, 2003; Accepted: December 31, 2003

Proofs received from author(s): March 22, 2004 